\title{
OPROSTITE, ČIJE SLOBODNO VRIJEME?! ISKUSTVO SLOBODNOG VREMENA OBITELJI DJETETA S TEŠKOĆAMA U RAZVOJU
}

\author{
EXCUSE ME, WHOSE LEISURE TIME?! \\ PERCEPTIONS OF FAMILY LEISURE AMONGST FAMILIES \\ WITH CHILDREN WITH DEVELOPMENTAL DISABILITIES
}

\author{
ANA BLAŽEVIĆ SIMIĆ ${ }^{1}$, MARIJA ĐURAŠIN

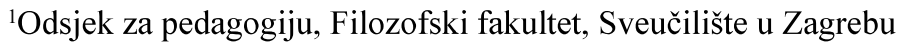

Primljeno/Received: 06.11.2019.

Prethodno priopćenje / Preliminary report

Prihvaćeno/Accepted: 04.05.2020.

UDK/UDC: 37-053.2-056.36:37-055.52"377"

doi: $10.31299 /$ hrri.56.1.9

\begin{abstract}
The purpose of the paper was to research leisure in families with children with developmental disabilities from the parents' point of view, a topic that has been marginally researched in Croatia as well as in the region. Qualitative methodology was used, and information was gathered by interviewing nine mothers of children with developmental disabilities. The results show that mothers achieve family leisure through a large spectrum of activities, during which they assign great importance to interaction. To organise family leisure, they face numerous challenges (e.g. stress, fatigue, difficulties in finding suitable activities) and use various strategies (e.g. planning carefully, obtaining materials, consulting other parents/experts). As benefits of family leisure, they report family member bonding, relaxation and fun for the child with developmental disability as well as maturity and empathy in the siblings of typical development. However, when asked whether they can use the family leisure as their own leisure, answers were contradictory.
\end{abstract}

Keywords: parents, challenges, strategies, benefits, qualitative research
Sažetak: Cilj ovog istraživanja bio je ispitati iskustvo slobodnog vremena obitelji djeteta s teškoćama u razvoju iz roditeljske perspektive, a koje je u okvirima hrvatske znanstvene zajednice, ali i zemljama regije, dosad tek marginalno tematizirano. Korištena je kvalitativna metodologija te su podaci prikupljeni intervjuiranjem devet majki djece s teškoćama u razvoju. Rezultati pokazuju da majke djece s teškoćama u razvoju slobodno vrijeme obitelji ostvaruju kroz širok spektar aktivnosti te kako prilikom njegova provođenja pridaju važnost interakciji. Pri provođenju slobodnog vremena obitelji majke se susreću s izazovima poput svakodnevnih obveza, stresa, umora te s teškoćama u pronalaženju aktivnosti koje odgovaraju interesima i mogućnostima različitih članova obitelji. Pri ostvarivanju slobodnog vremena obitelji majke koriste strategije poput pomnog planiranja, nabavljanja materijala i pomagala te konzultiranja s drugim roditeljima i stručnjacima s ciljem osiguravanja uspješnijeg slobodnog vremena obitelji. Kao dobrobiti slobodnog vremena obitelji majke prepoznaju povezivanje članova obitelji, razvoj, odmor i zabavu djeteta s teškoćama u razvoju te zrelost $i$ empatiju djeteta tipična razvoja. Kod pitanja mogu li slobodno vrijeme obitelji doživjeti kao slobodno vrijeme, majke daju podvojene odgovore, a od dobrobiti slobodnog vremena obitelji za njih same najviše navode odmor.

Ključne riječi: roditelji, izazovi, strategije, dobrobiti, kvalitativno istraživanje 


\section{INTRODUCTION}

Families of children with developmental disabilities in the Republic of Croatia come across difficulties in exercising their rights to upbringing, education and social welfare. For example, they have difficulties in obtaining adequate financial aid, which in the Republic of Croatia is guaranteed by the Social Welfare Act and the Ordinance on the Rights of Parents of a Child with More Serious Developmental Disabilities to Leave or Work HalfTime to Care for the Child, as well as other regulations. Families also have difficulties in accessing expert help due to the lack of experts specialised in educational, rehabilitation and therapy work and to the lack of support in financing such experts (Rešetar, 2017). When talking about ensuring the right to education, it is clear that there are elements of segregation practice in education. There are also difficulties in achieving appropriate educational programmes and appropriate means of assistance for education, which should be regulated by the Primary and Secondary School Education Act as well as Regulations on Primary and Secondary Education of Students with Developmental Disabilities (Report on the work for 2017, 2017).

In addition to the difficulties in exercising the above-mentioned rights, the sphere of family leisure with a child with a developmental disability is an even more ignored area, so we can talk about difficulties in ensuring the opportunities for leisure, meaning insufficient possibilities for achieving family leisure at home, an inadequate availability of activities outside the home and difficulties in participating in those activities, as well as difficulties in ensuring resources for such activities (Clarke, 2006).

Speaking of family leisure, it is necessary to first begin with a generally accepted basic definition of leisure in scientific circles as "set of occupations to which an individual may freely devote himself, whether for rest, for fun, for personal development or disinterested formation..." (Dumazedier, 1962, according to Janković, 1973, p. 34). Extending it in the family context, over the past several decades there is also one basic, generally accepted definition of family leisure as time that family members spend together in free

\section{UVOD}

Obitelji djece s teškoćama u razvoju u Republici Hrvatskoj nailaze na teškoće u ostvarivanju prava na odgoj i obrazovanje kao i prava na socijalnu skrb, bilo da je riječ o nedostatnosti mjera financijske pomoći, što se očituje u teškoćama u dobivanju odgovarajuće novčane naknade (koja, između ostalog, u Republici Hrvatskoj treba biti osigurana Zakonom o socijalnoj skrbi kao i Pravilnikom o pravima roditelja djeteta s težim smetnjama u razvoju na dopust ili na rad s polovicom punog radnog vremena radi njege djeteta), bilo da je riječ o nedostatnosti mjera stručne pomoći što se pak očituje u nedostatku stručnjaka specijaliziranih za edukacijsko-rehabilitacijski i terapeutski rad kao i nedostatku i/ili izostanku potpore u financiranju istih (Rešetar, 2017). Što se osiguravanja prava na obrazovanje tiče, očito je postojanje elemenata segregacijske prakse u obrazovanju kao i poteškoća u ostvarivanju primjerenih programa školovanja i primjerenih oblika pomoći školovanja (što bi trebalo biti regulirano Zakonom o odgoju i obrazovanju u osnovnoj i srednjoj školi kao i Pravilnikom o osnovnoškolskom i srednjoškolskom odgoju i obrazovanju učenika s teškoćama u razvoju) (Izvješće o radu Pravobranitelja za osobe s invaliditetom za 2017. godinu, 2017).

Povrh te opterećenosti u ostvarivanju navedenih prava, sfera slobodnog vremena obitelji djeteta $\mathrm{s}$ teškoćama u razvoju javlja se kao još zanemarenije područje pa se tako može govoriti o teškoćama u osiguravanja prilika za slobodno vrijeme, što podrazumijeva nedovoljne mogućnosti za provođenje slobodnog vremena obitelji kod kuće kao i nedovoljnu ponudu aktivnosti izvan kuće te teškoće u pristupu aktivnostima kao i teškoće u osiguravanju resursa za aktivnosti (Clarke, 2006).

Govoreći o pojmu slobodnog vremena obitelji nužno je najprije poći od, u znanstvenim krugovima, opće prihvaćene temeljne definicije slobodnog vremena kao "skupa aktivnosti kojima se čovjek predaje potpuno svojom voljom, bilo da se odmori ili razonodi bilo da razvije svoje spoznaje ili svoje bezinteresno formiranje..." (Dumazedier, 1962 prema Janković, 1973, 34). Proširujući navedenu definiciju u kontekstu obitelji, također se već nekoliko desetljeća ističe opća, uvriježena definicija 
Hrvatska revija za rehabilitacijska istraživanja 2020, Vol 56, br. 1, str. 107-131

time activities (Shaw, 1997, according to Hodge et al., 2015). However, that immediately imposes the need for a deeper understanding of the phenomenon of "leisure", which depends on whether family members even think of it as leisure (Shaw, 1997, according to McCabe, 2015). The above-mentioned implies that it is not always about freely chosen activities because family leisure is often seen as a duty and even though it can imply satisfaction, it often includes work, occasional frustrations and a possible lack of satisfaction of all family members (Shaw \& Dawson, 2001). Hence, the above-mentioned authors call it "serious leisure". Similar to that, it is also described as "purposive leisure", which means that it should be not only entertaining but also developmental, primarily for the child's development. It should give the child the opportunity to learn through family leisure. Therefore, family leisure should be planned and implemented in order to achieve certain goals, such as strengthening family cohesion. Lack of existence of a unique definition of family leisure is connected to the questions of whether it really is leisure (Shaw \& Dawson, 2001), which family members talk about that leisure, and in which phase of the cycle of life the family is (Hebblethwaite, 2015). Therefore, family leisure is characterised by identity markers of the family and its members.

Families achieve their leisure through various activities, which Zabriskie and McCormick (2001) divide into "core" and "balance". Core activities imply usual daily and relaxing activities that are done within or near the house. Balance activities are those more oriented toward gaining new experiences and achieving a change, and they demand more planning and resources from the family members. In addition, activities can be considered "joint" or "parallel" based on the level of interaction amongst family members. Joint activities are those defined by a high level of interaction amongst family members, while for parallel activities the interaction is low (Orthner, 1975, according to Melton, 2017). Melton (2017) integrates the above-mentioned differentiation into a family activity model by differentiating family leisure activities depending on the level of interaction amongst family members and the level of disparity between those activities and surrounding ones. slobodnog vremena obitelji kao vremena koje članovi obitelji provode zajedno sudjelujući u slobodnovremenskim aktivnostima (Shaw, 1997 prema Hodge i sur., 2015). No pritom se odmah nameće ključan dio dubljeg poimanja tog fenomena, a to je prije svega pitanje koliko ga članovi obitelji uopće doživljavaju kao slobodno vrijeme (Shaw, 1997, prema McCabe, 2015). Navedeno podrazumijeva da nije uvijek riječ o slobodno odabranim aktivnostima, već se na slobodno vrijeme obitelji nerijetko gleda kao na obvezu te iako ono može podrazumijevati zadovoljstvo, često istovremeno uključuje rad, povremene frustracije te mogući nedostatak zadovoljstva svih članova obitelji (Shaw i Dawson, 2001). Stoga ga navedeni autori opisuju terminom ozbiljnog slobodnog vremena (serious leisure). Slično tome opisuju ga i terminom namjerno slobodno vrijeme (purposive leisure) što znači da se njime ne smjera samo na zabavu, već i na razvoj, prije svega, djeteta, na pružanje prilika da se kroz slobodno vrijeme obitelji osiguraju iskustva za djetetovo učenje te da se slobodno vrijeme obitelji planira i provodi s namjerom postizanja određenih ciljeva poput jačanja obiteljske kohezije. Nepostojanje jedinstvene definicije slobodnog vremena obitelji vezuje se uz to je li zaista riječ o slobodnom vremenu (Shaw i Dawson, 2001), kao i uz to tko od članova obitelji govori o tom vremenu te uz to u kojoj se fazi životnog ciklusa obitelj nalazi (Hebblethwaite, 2015). Stoga je poimanje slobodnog vremena obitelji općenito obilježeno identitetskim markerima obitelji i njezinih članova.

Obitelji svoje slobodno vrijeme ostvaruju kroz različite aktivnosti koje Zabriskie i McCormick (2001) dijele na bazične i uravnotežujuće pri čemu prve podrazumijevaju uobičajene dnevne i opuštajuće aktivnosti koje se provode u kući ili u blizini kuće, a druge su one orijentirane na stjecanje novih iskustava i na promjenu te zahtijevaju od članova obitelji više planiranja i resursa. Usto, s obzirom na stupanj interakcije među članovima obitelji, razlikuju se povezujuće i usporedne aktivnosti pri čemu su povezujuće one koje određuje visok stupanj interakcije među članovima obitelji, dok je kod usporednih riječ o niskom stupnju interakcije (Orthner, 1975, prema Melton, 2017). Navedene diferencijacije Melton (2017) integrira u model obiteljskih aktivnosti (family activity model) 
Leisure for families of children with developmental disabilities has been the subject of less research, and the interest for that area has grown along with the understanding about the benefits of family leisure and changes in the perception of people with developmental disabilities in terms of the spread of inclusion (Mactavish \& Schleien, 2004).

\section{LEISURE ACTIVITIES OF FAMILIES WITH CHILDREN WITH DEVELOPMENTAL DISABILITIES}

In terms of previous research of leisure of families with a child with a developmental disability, what was researched was the type and the frequency of family leisure, and spending leisure was compared between families with a child with a developmental disability and families with a child of typical development. According to Mactavish and Schleien (2000), the most frequent leisure activities were the activities that fall into the category of physical recreation activities such as swimming, followed by passive activities such as watching TV and, least often, visiting family and friends. Axelsson and Wilder (2014) report that the families with children with profound intellectual and multiple disabilities practiced passive activities more often, i.e. more peaceful activities inside their homes, compared to the families that have a child with typical development, who participated more in activities outside their homes. The above-mentioned results on rarely practicing activities such as a holiday in families with a child with a developmental disability were confirmed by the research of leisure activities in families with a child with autism spectrum disorder (Rodger \& Umaibalan, 2011), which found that the balance activities of parties, celebrations and vacations were rarely practised.

Contrary to the above-mentioned identified differences in the quantity and the type of leisure activity in families with a child of a typical development and families with a child with a developmental disability, Dodd, Zabriskie, Widmer, and Eggett (2009) did not find differences in the level of participation in leisure activities between the above-mentioned family types, pointing to the same participation in core and balance leisure activities, just as Mactavish and Schleien (2004) did not find differences in the frequency of indoor razlikujući pritom slobodno vrijeme obitelji ovisno o stupnju interakcije među članovima obitelji te stupnju nepodudarnosti aktivnosti s okolinom.

Aktivnosti slobodnog vremena obitelji djeteta $\mathrm{s}$ teškoćama u razvoju bile su predmetom manjeg broja istraživanja, a interes za istraživanje tog područja rastao je jačanjem spoznaje o dobrobitima slobodnog vremena obitelji kao i promjenom pogleda na osobe s teškoćama u razvoju u smislu širenja prakse deinstitucionalizacije (Mactavish i Schleien, 2004).

\section{AKTIVNOSTI SLOBODNOG VREMENA OBITELJI DJETETA S TEŠKOĆAMA U RAZVOJU}

U sklopu dosadašnjih istraživanja slobodnog vremena obitelji djeteta s teškoćama u razvoju istraživane su vrste i učestalost aktivnosti slobodnog vremena obitelji pri čemu su, između ostalog, izvršene usporedbe načina na koji obitelji djeteta s teškoćama u razvoju provode slobodno vrijeme u odnosu na obitelji djeteta tipična razvoja. Prema Mactavish i Schleien (2000) najučestalijim aktivnostima slobodnog vremena pokazale su se aktivnosti svrstane pod kategoriju fizičkih aktivnosti poput plivanja, zatim pasivne aktivnosti poput gledanja televizije te naposljetku aktivnosti poput odlaska u goste. Axelsson i Wilder (2014) izvješćuju o tome kako su obitelji djeteta s više vrsta i stupnjeva teškoća u psihofizičkom razvoju češće prakticirale bazične aktivnosti, odnosno aktivnosti mirnijeg tipa unutar kuće, u odnosu na obitelji djeteta tipična razvoja koje su pak češće sudjelovale u aktivnostima izvan kuće. Navedeni rezultati o rjeđem prakticiranju aktivnosti poput odmora u obiteljima djeteta s teškoćama u razvoju potvrđeni su i kod istraživanja slobodnog vremena obitelji djeteta s poremećajem iz autističnog spektra (Rodger i Umaibalan, 2011), pri čemu se utvrdilo rjeđe prakticiranje zabava, proslava i odlazaka na odmor, odnosno uravnotežujućih aktivnosti.

Suprotno navedenim identificiranim razlikama u količini i vrstama aktivnosti slobodnog vremena obitelji između obitelji djeteta tipična razvoja i obitelji djeteta s teškoćama u razvoju, Dodd, Zabriskie, Widmer i Eggett (2009) ne pronalaze razlike u stupnju participacije u aktivnostima slobodnog vreme- 
or outdoor activities in families with a child with a developmental disability.

Unlike the earlier mentioned findings on the rare frequency of outdoor activities, Downs (2008) reported on the wide variety of such activities, stating that activities such as trampoline jumping, going to the beach or camping were often practised in families with a child with severe disabilities. Unlike the question of whether it is about indoor/ outdoor activities or core/balance leisure activities, the question of the level of family members' interaction in leisure activities has not been researched.

\section{CHALLENGES IN ACHIEVING LEISURE IN FAMILIES WITH CHILDREN WITH DEVELOPMENTAL DISABILITIES}

Speaking of family leisure in families with children with developmental disabilities, what is often mentioned are the difficult family routines structured around the child's disability (Boyd, Harkins McCarty, \& Sethi, 2014). Along with that, Mactavish and Schleien (2004) found that parents saw the need to plan extra and found it challenging to locate additional resources to achieve leisure and a balance between work and leisure. An additional challenge was the difficulty to find suitable activities that could benefit various interests and the abilities of the family members, especially for a child with a developmental disability (Mactavish \& Schleien, 2004).

Furthermore, Rodger and Umaibalan (2011) reported on the lack of formal and informal support to the families with a child with autism spectrum disorder as something that made achieving family leisure difficult. DeGrace (2004) stated that the difficulties in participating in joint activities in families with a child with autism can lead to parent dissatisfaction, especially guilt; it can hinder achieving family welfare; and it can have a negative influence on the family identity.

\section{STRATEGIES ON ACHIEVING LEISURE IN FAMILIES WITH CHILDREN WITH DEVELOPMENTAL DISABILITIES}

To face the challenges connected to organising and spending family leisure, families with a child with a developmental disability respond by creat- na između navedenih tipova obitelji ukazujući na jednaku participaciju u bazičnim i u uravnotežujućim aktivnostima slobodnog vremena, kao što ni Mactavish i Schleien (2004) ne pronalaze razlike u učestalosti aktivnosti unutar i aktivnosti izvan kuće kod obitelji djeteta s teškoćama u razvoju.

Također za razliku od ranije spomenutih rezultata istraživanja o rjeđem prakticiranju aktivnosti izvan kuće, Downs (2008) izvještava o širokom rasponu takvih aktivnosti navodeći aktivnosti poput skakanja na trampolinu, odlaska na plažu ili kampiranja kao često prakticirane aktivnosti kod obitelji djeteta s više vrsta i stupnjeva teškoća u psihofizičkom razvoju. Za razliku od pitanja je li riječ o aktivnostima izvan/unutar kuće ili bazičnim/ uravnotežujućim aktivnostima slobodnog vremena, pitanje stupnja interakcije članova obitelji u slobodnim aktivnostima nije istraživano.

\section{IZAZOVI U OSTVARIVANJU SLOBODNOG VREMENA OBITELJ DJETETA S TEŠKOĆAMA U RAZVOJU}

Kad se govori o slobodnom vremenu obitelji djeteta s teškoćama, nerijetko se govori i o otežanim obiteljskim rutinama koje gravitiraju oko teškoća djeteta (Boyd, Harkins McCarty i Sethi, 2014). S tim je povezana i potreba za dodatnim planiranjem i pronalaženjem potrebnih resursa za ostvarenje slobodnog vremena, kao i balansiranje između posla te slobodnog vremena obitelji što Mactavish i Schleien (2004) vide kao nešto što roditelji mogu percipirati kao opterećujuće. Usto kao izazov se navodi poteškoća u pronalaženju odgovarajućih aktivnosti koje bi odgovarale različitim interesima i sposobnostima članova obitelji, osobito djetetu s teškoćama u razvoju (Mactavish i Schleien, 2004).

Nadalje Rodger i Umaibalan (2011) izvješćuju o izostanku formalne i neformalne podrške obiteljima djeteta s poremećajem iz autističnog spektra kao nečemu što otežava ostvarivanje aktivnosti slobodnog vremena obitelji. DeGrace (2004) pak govori o tome kako teškoće u participaciji u zajedničkim aktivnostima kod obitelji djeteta s poremećajem iz autističnog spektra mogu voditi do osjećaja nezadovoljstva roditelja, osobito osjećaja krivnje, zatim do otežanog ostvarivanja dobrobiti obitelji te nepovoljnog utjecaja na obiteljski identitet. 
ing strategies that make it easier to participate in family leisure activities (Dodd et al., 2009). Segal (2011) speaks about the careful planning of the entire family in order to ensure the space and the time for the whole family to be together. With the additional goal of including all family members in joint leisure, families practice strategies such as preparing different food, aids, planning alternate plans, locations, time and participants in the activities, or they structure daily routines in a way to help the children cope with possibly negative sensory experiences (Bagby, Dickie, \& Baranek, 2012, according to Boyd et al., 2014). Families that have a child with autism often check and monitor the number of stimulations in the surrounding area and ensure routines with the goal of increasing the predictability of the experiences (Schaaf, TothCohen, Johnson, Outten, \& Benevides, 2011).

Connected with those strategies, DeGrace, Hoffman, Hutson and Kolobe (2014) talk about the family going from the feeling of paralysis through a research phase, which is characterised by the search for information, studying and searching for meaning by the parents; to an application phase, which implies taking action and which is connected to the feeling of confidence, reflexivity and hope by the parents.

\section{BENEFITS OF LEISURE IN FAMILIES WITH CHILDREN WITH DEVELOPMENTAL DISABILITIES}

Lastly, in the context of the research of leisure in families with a child with a developmental disability, the benefits of family leisure activities have also been the subject of research. However, the greater part of the research has placed the focus on the benefits for the child with a developmental disability. These benefits include the child's skill, confidence development, positive self-perception and the experience of fun, as well as the child's detachment from a stressful experience (Mactavish and Schleien, 1998; Mactavish and Schleien, 2004).

When talking about the benefits of family leisure for a child with a developmental disability, we can also talk about the benefits of leisure family activities for the whole family. In that manner, family participation in leisure activities

\section{STRATEGIJE OSIGURAVANJA} SLOBODNOG VREMENA OBITELJI DJETETA S TEŠKOĆAMA U RAZVOJU

$\mathrm{Na}$ izazove povezane s organiziranjem i provođenjem slobodnog vremena obitelji, obitelji djeteta s teškoćama u razvoju odgovaraju kreiranjem strategija koje olakšavaju sudjelovanje u aktivnostima slobodnog vremena obitelji (Dodd i sur., 2009). Segal (2011) tako govori o pažljivom planiranju kako bi se osigurali prostor i vrijeme da obitelj može biti zajedno. Također s ciljem uključivanja svih članova obitelji u zajedničko slobodno vrijeme, obitelji prakticiraju strategije poput pripremanja različite hrane, pomagala, planiranja alternativnih planova, planiranja lokacije, vremena i sudionika $u$ aktivnostima ili pak strukturiraju dnevne rutine na način da djeci olakšaju nošenje s potencijalno neugodnim podražajima (Bagby, Dickie i Baranek, 2012, prema Boyd i sur., 2014). Obitelji djeteta s poremećajem iz autističnog spektra često provjeravaju i nadziru količinu podražaja u okruženju te osiguravaju rutine s ciljem povećanja predvidljivosti iskustava (Schaaf, Toth-Cohen, Johnson, Outten i Benevides, 2011).

Sukladno navedenim strategijama DeGrace, Hoffman, Hutson i Kolobe (2014) govore o roditeljskom polaženju od faze osjećaja paraliziranosti preko faze istraživanja, koju karakterizira traženje informacija, proučavanje te traženje smisla pa do faze primjene koja podrazumijeva poduzimanje akcija, a koja je povezana s osjećajem samopouzdanja, refleksivnosti i nade kod roditelja.

\section{DOBROBITI SLOBODNOG VREMENA OBITELJI DJETETA S TEŠKOĆAMA U RAZVOJU}

Naposljetku, u kontekstu istraživanja slobodnog vremena obitelji djeteta s teškoćama u razvoju dobrobiti aktivnosti slobodnog vremena obitelji također su bile predmetom istraživanja, međutim veći dio istraživanja fokus je stavljao na dobrobiti za dijete $s$ teškoćama u razvoju s čim u vezi se navode razvoj vještina djeteta, razvoj samopouzdanja i pozitivnog samopoimanja djeteta te iskustvo zabave kao i djetetovo odmicanje od stresnog iskustva (Mactavish i Schleien, 1998; Mactavish i Schleien, 2004). 
is described as a chance for moments filled with happiness (Downs, 2008), a way of re-establishing the meaning of what is important in life, a way of improving communication amongst family members (Mactavish and Schleien, 2004), and as a way of connecting family members and developing the quality of family life (Mactavish and Schleien, 1998).

When talking about the benefits of family leisure for the parents themselves, Downs (2008) reported on parents' statements, which described leisure activities as significant and useful for the feeling of their own parental efficiency, the feeling of normalcy and the feeling of control over life and environment. What is lacking are findings on the potential benefits of family leisure for other family members, primarily brothers and sisters of the child with a developmental disability, i.e. the children of typical development.

\section{STUDY PURPOSE AND RESEARCH QUESTIONS}

The purpose of this research was to gain insight into the leisure experience in families with a child with a developmental disability from the parents' perspective. The following questions were asked:

1. In what way do families with children with developmental disabilities spend their leisure time?

2. What challenges do the parents of children with developmental disabilities face in achieving family leisure?

3. What strategies do the parents of children with developmental disabilities use for achieving family leisure?

4. How do parents of children with developmental disabilities perceive family leisure benefits and do they perceive family leisure as leisure?

It is interesting to mention that, while searching for the sample of participants, it was important to emphasise to the parents of children with developmental disabilities that the research was not about solely the child's leisure but that of the family as a whole. Their first question after hearing of the study's aims was often, "Excuse me, whose leisure time?!" This was the first signal to the authors of
Uz navođenje dobrobiti slobodnog vremena obitelji za dijete s teškoćama u razvoju prisutan je i navod o dobrobitima aktivnosti slobodnog vremena obitelji za cijelu obitelj pri čemu se obiteljska participacija u aktivnostima slobodnog vremena opisuje kao prilika za trenutke ispunjene srećom (Downs, 2008) te kao način ponovnog uspostavljanja smisla onoga što je u životu važno kao i način poboljšanja komunikacije među članovima obitelji (Mactavish i Schleien, 2004), ali i kao način povezivanja članova obitelji te razvijanja kvalitete obiteljskog života (Mactavish i Schleien, 1998).

Kod spominjanja dobrobiti slobodnog vremena obitelji za same roditelje Downs (2008) izvještava o iskazima roditelja koji aktivnosti slobodnog vremena opisuju kao značajne i korisne za osjećaj vlastite roditeljske učinkovitosti, osjećaj prosječnosti te osjećaj kontrole nad životom i okolinom. Što se tiče nalaza o potencijalnim dobrobitima slobodnog vremena obitelji za ostale članove obitelji, prije svega braću i sestre djeteta s teškoćama u razvoju, odnosno djecu tipična razvoja, primjetno je kako oni izostaju.

\section{SVRHA ISTRAŽIVANJA I ISTRAŽIVAČKA PITANJA}

Cilj ovog istraživanja bio je dobiti uvid u iskustvo slobodnog vremena obitelji djeteta s teškoćama u razvoju iz roditeljske perspektive. Nastojalo se odgovoriti na sljedeća istraživačka pitanja:

1. Na koji način obitelji djeteta s teškoćama u razvoju provode slobodno vrijeme?

2. S kojim se izazovima roditelji djece s teškoćama u razvoju susreću u ostvarivanju slobodnog vremena obitelji?

3. Koje strategije roditelji djece s teškoćama u razvoju koriste za ostvarivanje slobodnog vremena obitelji?

4. Kako roditelji djece s teškoćama u razvoju percipiraju dobrobiti slobodnog vremena obitelji i doživljavaju li slobodno vrijeme obitelji kao slobodno vrijeme?

Zanimljivo je spomenuti kako se prilikom traženja uzorka ispitanika, roditeljima djece s teškoćama u razvoju najprije moralo naglasiti kako u istraživanju neće biti riječi isključivo o slobodnom vremenu djeteta, već obitelji kao cjeline. Njihovo je učestalo uvodno pitanje "Oprostite, čije slobodno vrijeme?!" stoga 
how much the concept of family leisure as such has been neglected.

\section{METHODS}

The research was conducted by individually interviewing the female participants/mothers of children with developmental disabilities. Before the beginning of the interview, participants were informed about the study purpose and benefits, interview mode, duration and recording, their right to withdraw from participation and, if they wished, to learn of the research results. The participants signed the consent and thereby confirmed their voluntarily participation and familiarity with the research details. The average interview duration was 30 minutes.

The sample was convenience, non-probabilistic and was made by nine mothers of children with developmental disabilities $(\mathrm{N}=9)$ (Table 1). Six people questioned were interviewed in their family homes, two in a local café and one in a local family centre. Their age ranged from 32 to 49 years of age. Seven mothers were from a larger Croatian town (more than 50,000 inhabitants) and two from a smaller town (fewer than 50,000 inhabitants).

Five mothers had two children, three had one and one had three. Eight mothers had one child with a developmental disability, and one had two. Four mothers had a child with autism spectrum disorder, two had children with cerebral palsy, two had children with several types and levels of disability in psychophysical development, one had a child with chromosome deletion syndrome and one had a child with attention-deficit/hyperactivity disorder. Seven children with developmental disabilities were male and three were female. The age of children with developmental disabilities ranged from 5 to 17 years of age.

A semi-structured in-depth interview was used for collecting data, and exploratory research was conducted. The semi-structured interview was based on the literature overview and independently constructed questions based on the need of this research, and it consisted of questions on general features of the mothers (the age, place of residence, number of children in the family, number of children with developmental disabilities, the autoricama bio prvi signal zanemarenosti koncepta slobodnog vremena obitelji kao takvog te je zbog toga predstavljalo pogodan odabir za naslov rada.

\section{METODE RADA}

Istraživanje je provedeno individualnim intervjuiranjem ispitanica/majki djeteta s teškoćama u razvoju. Prije početka intervjua ispitanice su obaviještene o cilju i koristima istraživanja, načinu rada, trajanju i snimanju intervjua, pravu na odustajanje od sudjelovanja te mogućnosti uvida u rezultate istraživanja ukoliko to zatraže. Ispitanice su potpisale suglasnost kojom su potvrdile dobrovoljno sudjelovanje i upoznatost s pojedinostima istraživanja. Prosječno trajanje intervjua bilo je 30 minuta.

Uzorak je bio prigodan, neprobabilistički, a činilo ga je devet majki djeteta s teškoćama u razvoju $(\mathrm{N}=9)$ (v. Tablicu 1). Šest ispitanica intervjuirano je u njihovu obiteljskom domu, dvije u lokalnom kafiću, a jedna u lokalnom obiteljskom centru. Dob ispitanica kreće se u rasponu od 32 do 49 godina. Sedam je ispitanica iz većeg hrvatskog grada (više od 50000 stanovnika), a dvije su ispitanice iz manjeg (manje od 50000 stanovnika).

Pet ispitanica ima dvoje djece, tri imaju jedno, a jedna ispitanica ima troje djece. Osam ispitanica ima jedno dijete s teškoćama u razvoju, a jedna ih ima dvoje. Cetiri ispitanice imaju dijete s poremećajem iz autističnog spektra, dvije imaju dijete $s$ cerebralnom paralizom, dvije dijete s više vrsta i stupnjeva teškoća u psihofizičkom razvoju, jedna dijete sa sindromom kromosomske delecije, a jedna ima dijete s deficitom pažnje/hiperaktivnim poremećajem. Sedmero djece s teškoćama u razvoju muškog je roda, a troje ženskog. Dob djece s teškoćama u razvoju kreće se od 5 do 17 godina.

Za prikupljanje podataka korišten je dubinski polustrukturirani intervju te je provedeno eksplorativno istraživanje. Polustrukturirani intervju temeljio se na pregledu literature i za potrebe ovog istraživanja samostalno konstruiranim pitanjima te se sastojao od pitanja o općim obilježjima ispitanica (dob ispitanica, mjesto stanovanja, broj djece u obitelji, broj djece s teškoćama u razvoju, teškoća djeteta, rod djeteta s teškoćama u razvoju, dob djeteta s teškoćama u razvoju) te pitanja koja su se odnosila na četiri istraživačka pitanja. 
Table 1. Participant characteristics/ Obilježja uzorka ispitanica

\begin{tabular}{|c|c|c|c|c|c|c|c|}
\hline $\begin{array}{l}\text { Participant } \\
\text { ID }\end{array}$ & $\begin{array}{c}\text { Participant } \\
\text { Age }\end{array}$ & \begin{tabular}{|c|} 
Place of \\
Residence
\end{tabular} & $\begin{array}{l}\text { Number of } \\
\text { Children in } \\
\text { the Family }\end{array}$ & \begin{tabular}{|c|} 
Number of \\
Children with \\
Developmental \\
Disabilities
\end{tabular} & The Child's Disability & \begin{tabular}{|c|}
$\begin{array}{c}\text { The Gender } \\
\text { of the Child } \\
\text { with a } \\
\text { Developmental } \\
\text { Disability }\end{array}$ \\
\end{tabular} & \begin{tabular}{|c|} 
The Age of the \\
Child with a \\
Developmental \\
Disability \\
\end{tabular} \\
\hline M1 & 35 & $\mathrm{LT}^{*}$ & 2 & 1 & $\begin{array}{l}\text { Several Types and } \\
\text { Levels of Disability } \\
\text { in Psychophysical } \\
\text { Development }\end{array}$ & $\mathrm{F}$ & 7 \\
\hline M2 & 40 & LT & 2 & 1 & Cerebral Palsy & $\mathrm{M}$ & 16 \\
\hline M3 & 39 & LT & 1 & 1 & $\begin{array}{l}\text { Autism Spectrum } \\
\text { Disorder }\end{array}$ & $\mathrm{M}$ & 8 \\
\hline M4 & 32 & LT & 2 & 1 & $\begin{array}{l}\text { poremećaj iz autističnog } \\
\text { spektra }\end{array}$ & $\mathrm{M}$ & 8 \\
\hline M5 & 37 & LT & 3 & 2 & $\begin{array}{l}\text { Cerebral Palsy } \\
\text { Attention Deficit/ } \\
\text { Hyperactivity Disorder }\end{array}$ & $\begin{array}{l}\mathrm{F} \\
\mathrm{M}\end{array}$ & $\begin{array}{l}17 \\
15\end{array}$ \\
\hline M6 & 39 & $\mathrm{LT}$ & 1 & 1 & $\begin{array}{l}\text { Chromosome Deletion } \\
\text { Syndrome }\end{array}$ & $\mathrm{M}$ & 13 \\
\hline M7 & 36 & $\mathrm{LT}$ & 1 & 1 & $\begin{array}{l}\text { Autism Spectrum } \\
\text { Disorder }\end{array}$ & $\mathrm{M}$ & 9 \\
\hline M8 & 36 & $\mathrm{ST}^{* *}$ & 2 & 1 & $\begin{array}{l}\text { Several Types and } \\
\text { Levels of Disability } \\
\text { in Psychophysical } \\
\text { Development }\end{array}$ & $\mathrm{F}$ & 5 \\
\hline M9 & 49 & ST & 2 & 1 & $\begin{array}{l}\text { Autism Spectrum } \\
\text { Disorder }\end{array}$ & $\mathrm{M}$ & 11 \\
\hline
\end{tabular}

$*$ LT $=$ larger town

$* * \mathrm{ST}=$ smaller town

child's disability, the gender of the child with a developmental disability, the age of the child with a developmental disability) and of questions that were related to the four research questions.

The first research question was related to the way that families with a child with developmental disability spend their leisure and it encompassed questions on the types of family leisure activities, the location of these activities, the frequency, the level of interaction during those activities and the family members that participate in those activities. The second research question was related to the challenges that the parents of the children with developmental activities face in achieving their leisure, and it encompassed questions about the everyday obligations as something that can hinder achieving family leisure, the ease with which leisure activities that match the interests and the abilities of various family members are found, stress and fatigue as challenging factors and the
Prvo istraživačko pitanje odnosilo se na način na koji obitelji djeteta s teškoćama u razvoju provode slobodno vrijeme te je obuhvatilo pitanja o vrstama aktivnosti slobodnog vremena obitelji, mjestu provođenja aktivnosti, učestalosti provođenja aktivnosti, stupnju interakcije tijekom istih te članovima obitelji koji sudjeluju u aktivnostima slobodnog vremena obitelji. Drugo istraživačko pitanje ticalo se izazova s kojima se roditelji djece $s$ teškoćama u razvoju susreću u ostvarivanju slobodnog vremena obitelji te je obuhvatilo pitanja o svakodnevnim obvezama kao nečemu što može otežavati ostvarivanje slobodnog vremena obitelji, lakoći pronalaženja aktivnosti slobodnog vremena koje odgovaraju interesima i mogućnostima različitih članova obitelji, zatim pitanje o stresu i umoru kao otežavajućim faktorima te pitanje o procjeni potrebnih resursa kako bi se osiguralo više zajedničkog slobodnog vremena obitelji. Treće istraživačko pitanje odnosilo se na strategije koje roditelji djece s teškoćama u razvoju 
resources necessary to achieve more joint family leisure. The third research question was related to the strategies that parents of children with developmental disabilities use to achieve family leisure and it included questions on family leisure planning, ensuring routines, additional materials and aids, reading literature that deals with the topic of developmental disabilities and community support in planning and achieving family leisure. The fourth research question was related to the benefits of leisure for families that have a child with developmental disability and the parents' perception of the benefit of leisure for the family, for the child with a developmental disability, for the parent, for the child with typical development and the perception of family leisure as leisure.

The interviews were conducted according to the protocol, and the course of the interview was flexibly modified according to the answers, which means that the sequence of the questions was adapted during the interview and the mothers were encouraged to give more detailed responses and additional explanations of what was said.

Qualitative methodology was used for data processing, i.e. quality content analysis was conducted. Hsieh and Shannon $(2005,1278)$ define quality analysis as a "research method for the subjective interpretation of the content of text data through the systematic classification process of coding and identifying themes or patterns". More concretely, an interpretative phenomenological analysis was conducted. Data process started by listening to audio files, transcribing and precisely reading transcribed interviews with the purpose of getting to know the data. The coding process was conducted, which means that the mothers' statements were transferred to codes, i.e. related words, sentences or ideas put under the same code that links them. (For example when talking about the types of family leisure activities, some of the mothers mentioned playing on a playground, which was coded under GAMPARK.) Then the frequency of the mothers giving that answer under the same code was determined.

However, the intention was not to quantify the results or to generalise them but to do the analysis of understanding the significance the mothers gave to the research subject. After determining the codes and their frequencies, similar codes were put into koriste za ostvarivanje slobodnog vremena obitelji te je uključivalo pitanja o planiranju slobodnog vremena obitelji, osiguravanju rutina, dodatnih materijala $\mathrm{i}$ pomagala, čitanju literature koja se bavi tematikom teškoća u razvoju te podršci okoline pri planiranju i ostvarivanju slobodnog vremena obitelji. Četvrto istraživačko pitanje odnosilo se na dobrobiti slobodnog vremena obitelji djeteta s teškoćama u razvoju i roditeljski doživljaj slobodnog vremena obitelji kao slobodnog vremena te je obuhvatilo pitanja o percepciji koristi slobodnog vremena obitelji za obitelj, za dijete s teškoćama u razvoju, za roditelja, za dijete tipična razvoja te pitanje o percepciji slobodnog vremena obitelji kao slobodnog vremena.

Intervjui su vođeni prema protokolu pri čemu je tijek intervjua fleksibilno modificiran ovisno o odgovorima ispitanica, što znači da je redoslijed pitanja prilagođavan prilikom intervjuiranja te su ispitanice poticane na bogatije odgovore i dodatna objašnjenja izrečenog.

Za obradu podataka korištena je kvalitativna metodologija, odnosno provedena je kvalitativna analiza sadržaja. Hsieh i Shannon (2005, 1278), kvalitativnu analizu sadržaja određuju kao "istraživačku metodu subjektivne interpretacije tekstualnog sadržaja kroz sistematičan klasifikacijski proces kodiranja i identificiranja tema ili obrazaca". Konkretnije provedena je interpretativnofenomenološka analiza. Postupak obrade podataka započeo je preslušavanjem audio zapisa, transkribiranjem te preciznim iščitavanjem transkribiranih sadržaja intervjua s ciljem upoznavanja s podacima. Potom je proveden postupak kodiranja što znači da su iskazi ispitanica svedeni na kodove, odnosno, srodne riječi, rečenice ili ideje svrstane su pod isti kod koji ih povezuje (primjerice kod govora o vrstama aktivnosti slobodnog vremena obitelji dio ispitanica naveo je igru u dječjem parku što je onda svrstano pod kod IGR-PARK), a potom je određena frekvencija ispitanica koje su navodile odgovor pod istim kodom.

Međutim namjera nije bila kvantifikacija rezultata ni njihovo poopćavanje, već analiza shvaćanja značenja koje ispitanice pridaju predmetu istraživanja. Nakon određivanja kodova i njihovih frekvencija srodni su kodovi svrstani u kategorije. Dakle kodiranje je provedeno ručno, a kodovi i kategorije derivirani su iz samih podataka. 
categories. Therefore, the coding was conducted manually and the codes and the categories were derived from the data.

\section{RESULTS AND DISCUSSION}

The received data were analysed according to the predefined research questions and compared to previous knowledge from earlier research. Therefore, the results overview is divided into four sections. The first section discusses the ways that families with children with developmental disabilities spend their leisure, the second section discusses the challenges to achieving family leisure in families with children with developmental disabilities, the third section discusses parents' strategies used for achieving family leisure, and the fourth section discusses benefits of family leisure as well as parents' experience of family leisure as leisure.

\section{HOW FAMILIES WITH CHILDREN WITH DEVELOPMENTAL DISABILITIES SPEND THEIR LEISURE TIME}

The first research question pointed to the wide spectrum of leisure activities in families with children with developmental disabilities. Mothers talked about various balance and core activities, but mostly they mentioned balance activities such as summer vacation or travelling in general; the core activities conducted outside the house, such as walks and playing in a park; and core activities inside the house, such as playing in the house and watching TV. Such results are similar to the findings of Downs (2008), who reported on the wide spectrum of outdoor activities amongst families with children with severe disabilities, such as jumping on the trampoline, going to the beach or camping.

We try to do it as many times as possible as a family, most often while walking the dogs in the park, now that the weather is nicer, and when the weather is not nice, when it is cold, then we are outside for a very short period of time or we go to the malls or playrooms. (M1)

Somehow they like best the outside playtime together... Let's run, chase, race, hide. There they find they have some common interests. The place where we are all together as a family is a swimming pool. (M4)

\section{REZULTATI I RASPRAVA}

Dobiveni podaci analizirani su prema postavljenim istraživačkim pitanjima te uspoređeni s dosadašnjim spoznajama ranijih istraživanja, stoga slijedi pregled rezultata podijeljen u četiri potpoglavlja. Prvo će potpoglavlje raspraviti načine na koje obitelji djeteta s teškoćama u razvoju provode slobodno vrijeme, drugo s kojim se izazovima susreću roditelji djece s teškoćama u razvoju u ostvarivanju slobodnog vremena obitelji, treće roditeljske strategije korištene za ostvarivanje slobodnog vremena obitelji te četvrto percepciju dobrobiti slobodnog vremena obitelji kao i doživljaj slobodnog vremena obitelji kao slobodnog vremena.

\section{NAČINI NA KOJE OBITELJI DJECE S TEŠKOĆAMA U RAZVOJU PROVODE SLOBODNO VRIJEME}

Prvo istraživačko pitanje ukazuje na širok spektar aktivnosti slobodnog vremena obitelji djeteta s teškoćama u razvoju. Majke govore o različitim uravnotežujućim i bazičnim aktivnostima pri čemu najviše spominju uravnotežujuće aktivnosti poput ljetovanja i putovanja općenito, zatim bazične aktivnosti koje provode izvan kuće poput šetnji i igre u parku te bazične aktivnosti unutar kuće poput igre i gledanja televizije. Takvi rezultati slični su onima koje navodi Downs (2008) izvještavajući o širokom rasponu aktivnosti izvan kuće, poput skakanja na trampolinu, odlaska na plažu ili kampiranja kod obitelji djeteta s više vrsta i stupnjeva teškoća u psihofizičkom razvoju.

Trudimo se to napraviti što je više moguće zajedno, najčešće u šetnji sa psima u parku, sad kad je ljepše vrijeme, a kada nije lijepo vrijeme, kad je zima, onda ili vrlo kratko vani ili šoping centri i igraonice. (M1)

Nekako najviše vole zajedno, ovoga, najviše igre na otvorenom... 'Ajmo trčat', lovit'se, utrkivat'se, skrivat'se. Tu su, recimo, di je njihov interes kol'ko toliko zajednički. Ovaj, baš di smo svi na nešto, di smo svi baš kompletno familijarno fokusirani, to je bazen. (M4)

Govoreći o mjestu provođenja slobodnog vremena obitelji, majke izvješćuju o mjestima izvan kuće poput parka i dvorišta te kući ili stanu. Mjesto 
When speaking of the place of spending family leisure, mothers reported places outside of the home, such as a park or a backyard, but also house or a flat. The place for achieving those activities was related to the possibilities it offered for achieving activities and the preparations it requires for conducting those activities. Family leisure activities were spent mostly outdoors because they enabled the child's participation, or were more often conducted indoors because of the need for additional equipment necessary for outdoor activities.

In the flat. Indoors. That is the simplest, the most comfortable and everything I need is here. So, for any outdoor activity, I need additional equipment. (M6)

Well, I would say nature. Mostly we are in nature, somewhere in a park. Or, we can sit in the car and we go outside for a walk. But mostly we are in nature, where, let's say, he is free and where his problem is the least visible. (M4)

The frequency of core activities varied depending on the number of obligations, and such activities were usually conducted daily, although more time was found at the weekends, while balance activities such as traveling and excursions occurred several times a year. In relation to that, mothers mentioned the need for planning and organising, as well as a routine when conducting such activities. Zabriskie and McCormick (2001) talk about balance activities as activities that are oriented toward gaining new experience and achieving a change, which they describe as activities that require more planning and resources from family members. Therefore, it is not illogical for the mothers to report on conducting balance activities less frequently in relation to core activities, as established earlier by Rodger and Umaibalan (2011) while researching family leisure in families with a child with autism spectrum disorder.

Every day, that happens every day. It just depends if it is more or less. So, it doesn't necessarily mean I get to do everything with him every day, but we are here every day. Or we watch, comment on a cartoon, and there are picture books on the table. (M6)

Interaction during joint leisure activities was shown as something that mothers perceive as odvijanja aktivnosti stavljaju u odnos s mogućnostima koje ono nudi za ostvarivanje aktivnosti te pripremama koje mjesto iziskuje za provođenje aktivnosti. Tako se aktivnosti slobodnog vremena obitelji više provode na otvorenom jer olakšavaju sudjelovanje djeteta ili se pak češće provode u kući što se vezuje s potrebom za dodatnom opremom nužnom za ostvarivanje aktivnosti izvan kuće.

U stanu. Unutra. To je ipak nekako najjednostavnije, najkomotnije i sve što mi treba je ovdje. Znači, za bilo kakav izlazak van, to već zahtijeva dodatnu opremu. (M6)

$P a$, rekla bih priroda. Najčešće smo u prirodi, negdje u parku. Ili, ovoga, znamo sjest' u auto pa odemo van $u^{* * * *}$ se prošetat'. Ali najčešće smo $u$ prirodi, di, ovaj, 'ajmo reći, ima najveću slobodu $i$ najmanje je izražen taj njegov problem. (M4)

Učestalost bazičnih aktivnosti varira s obzirom na količinu obaveza te se takve aktivnosti najčešće ostvaruju svaki dan, pri čemu se za njih više vremena pronalazi vikendom, dok se uravnotežujuće aktivnosti, posebice putovanja i izleti, prakticiraju nekoliko puta godišnje u vezi s čime majke spominju potrebu za planiranjem i organiziranjem, ali i uhodanost u provođenju takvih aktivnosti. O uravnotežujućim aktivnostima kao aktivnostima koje su orijentirane na stjecanje novih iskustava i na promjenu također govore Zabriskie i McCormick (2001) kad ih opisuju kao aktivnosti koje zahtijevaju od članova obitelji više planiranja i resursa. Stoga nije nelogično da ispitanice izvješćuju o rjeđem prakticiranju uravnotežujućih aktivnosti u odnosu na bazične, a što su i ranije utvrdile Rodger i Umaibalan (2011) u okviru istraživanja slobodnog vremena obitelji djeteta s poremećajem iz autističnog spektra.

Svaki dan, to se svaki dan događa. Samo ovisno je li više ili manje. Znači, ne mora biti sad nužno da ja sad svaki dan s njim sve to napravim, ali svaki dan smo tu. Ili pogledamo, komentiramo neki crtić, onda tu na stolu bude nekakvih slikovnica. (M6)

Interakcija tijekom aktivnosti zajedničkog slobodnog vremena pokazala se kao nešto što majke percipiraju važnim za uspješnost aktivnosti te prilikom provođenja aktivnosti istoj pridaju pažnju.

Ne možeš ju pustit' solo, ona treba pomoć $i$ podršku, u smislu da svaku aktivnost trebaš razbiti na manje dijelove, pa se onda o puno stvari 
Hrvatska revija za rehabilitacijska istraživanja 2020, Vol 56, br. 1, str. 107-131

important for an activity to be successful and to which mothers pay attention during an activity.

You can't let her go alone, she needs help and support, in the sense that you have to break every activity into smaller parts, and then you have to talk about a lot of things, and then we play. That is the only way in which you can have fun with her or she with you. To go down on all fours and act out whatever it takes so she can play as well. (M1)

When talking about the family members who participate in family leisure, some of the mothers talked about the participation of more family members, such as mother, father, and a child/children. Some of the mothers talked about the participation of fewer family members, in which case the mother participated more than the father. What is also described is the exchange between the mother and the father in the activities. Mothers' answers suggest that not all members participate in family leisure, that the mother and child are the ones who participate more, which is similar to findings by Mactavish and Schleien (2004). Nevertheless, that previous study and ours found that fathers also participated, which cautions against overemphasising the greater participation of the mother in family leisure than the father (Visković, 2016).

Yes, mostly me because my husband works all day, he comes home around 8 o'clock. But at the weekend he spends more time with him, I don't go to the swimming pool. The two of them spend all afternoon at the swimming pool. Most often until... the evening. That means that my husband is with him at the weekends. And I am on the work days. (M3)

\section{CHALLENGES IN ACHIEVING FAMILY LEISURE IN FAMILIES WITH CHILDREN WITH DEVELOPMENTAL DISABILITIES}

Responses to the second research question suggest that the everyday obligations that hinder achieving family leisure in families that have a child with developmental disabilities involve taking the child with a developmental disability to therapy and giving practical support to that child. Furthermore, the mother's fatigue and stress were described as something that hinders achieving family leisure, so mothers reported not achieving planned activities and reducing family leisure from razgovora, onda se i mi igramo. To je jedini način na koji se možeš zabavljat's njom, odnosno ona s tobom. Da se spustiš na sve četiri i odglumiš što god treba da se poigra i ona. (M1)

Što se tiče članova obitelji koji sudjeluju u slobodnom vremenu obitelji, dio ispitanica govori o sudjelovanju većeg broja članova obitelji što podrazumijeva majku, oca i dijete/djecu. Jedan dio ispitanica pak govori o sudjelovanju manjeg broja članova obitelji govoreći o većem angažmanu majki u odnosu na očeve. Usto, izmjenjivanje majke i oca u aktivnostima slobodnog vremena obitelji također se opisuje kao slučaj. Odgovori ispitanica sugeriraju kako u aktivnostima slobodnog vremena obitelji ne sudjeluju uvijek svi članovi obitelji, već nekad češće u tim aktivnostima sudjeluje majka s djetetom/djecom, što je slično nalazima Mactavish i Schleien (2004), ali se ovdje također izvješćuje i o sudjelovanju očeva što ide u prilog tezi o preuveličavanju proglasa o većoj uključenosti majki u slobodno vrijeme obitelji u odnosu na očeve (Visković, 2016).

Da, najviše ja jer muž radi po cijeli dan, oko osam sati dođe kući. Al'vikendom je muž često s njim, ja na bazen ne idem. Njih dva idu na bazen po cijelo poslije podne. I najčešće tamo pred večer do*****. Znači vikendom je muž s njim. A ja sam radnim danima. (M3)

\section{IZAZOVI U OSTVARIVANJU SLOBODNOG VREMENA OBITELJ DJETETA S TEŠKOĆAMA U RAZVOJU}

Drugo istraživačko pitanje sugerira kako svakodnevne obveze koje otežavaju ostvarivanje slobodnog vremena obitelji djeteta s teškoćama u razvoju gravitiraju oko odvođenja djeteta s teškoćama u razvoju na terapije i pružanja praktične podrške djetetu s teškoćama u razvoju. Nadalje umor i stres majke opisuju kao nešto što otežava ostvarivanje slobodnog vremena obitelji pa tako navode neostvarivanje planiranih aktivnosti i reduciranje slobodnog vremena obitelji tijekom vremena zbog umora te spominju stanje napetosti koje je prisutno prilikom provođenja slobodnog vremena obitelji.

Pa ovaj, ja znači, ja radim samo ujutro. Tako da smo popodne slobodni, ovaj, al'tu je ono di se vrte te terapije u nekakvim terminima suludim, onda ili 
time to time because of fatigue. They also reported tension that might be present during family leisure.

So, I work only in the morning. So in the afternoon, we are free, but, there is this thing where we have therapy at some crazy time, so then either only one [parent] goes or we all go together. And then we play with ***... or we talk in the car or I don't know. But it is, in a way, because the whole tempo wears you down and exhausts you, and not sleeping at night, so sometimes you are just too exhausted to go anywhere although you planned to do something. Then we stay at home and we play indoors. And we postpone activities for some other time. (M4)

Finding activities that suit the interests and the possibilities of various family members is something that not all mothers described as easily achieved. What is important is monitoring the interests and abilities of the child with a developmental disability and forming family leisure accordingly. Segal (2011) describes dedicated parents as those who focus on the child's interests and subordinate their own interests to the child's. We can ask the question whether the interests of the child with a developmental disability, in the context of family leisure activities, match those of other family members, or whether the activities are easily found because they are mostly the ones that match only the child's interests. Regardless, the second statement shows the importance of adapting family leisure activity to the child with a developmental disability, so that the family can practice activities that can satisfy a greater number of family members' interests.

Well, it is not easy. It is not easy. I say when we only start with the board games, which are not adapted to everyone and where it is really difficult to find a board game that can be played by everyone. And I don't know, going to the town where there are a ton of physical barriers. (M5)

Yes. She is a very interested child... whatever we do, we can do that with her. So she can participate in something, we simplify it as much as possible... There, for example, if we want to play the board game "Don't get angry", she cannot sit and follow the figures and all that. So we make it suit her needs. So we have made a giant board game with really big figures and with bright colors, with high contrast and in such a way that she ide jedan samo ili idemo svi zajedno. Pa se onda, ne znam, $s * * *$ ili igramo ili razgovaramo u autu ili ne znam... Ali, bude ono, na neki način da, jer cijeli taj tempo te izmori i iscrpi, i nespavanje po noći, tako da možda nekad i ono što si planirao da bi otišao jednostavno si premoren da bi išao bilo gdje. Onda se to ipak odlučimo zatvorit' u kuću i onda se igramo unutra. Pa opet odgodimo za neki drugi dan. (M4)

Pronalaženje aktivnosti koje odgovaraju interesima i mogućnostima različitih članova obitelji ne opisuju sve majke kao lako, a povezano s lakoćom važnim se pokazalo praćenje interesa i mogućnosti djeteta s teškoćama u razvoju te oblikovanje slobodnog vremena obitelji prema tome. Fokus na interese djeteta Segal (2011) opisuje kao predanost roditelja da svoje interese često podrede djetetovim s čim u vezi može se postaviti pitanje odgovaraju li interesi djeteta s teškoćama u razvoju, u kontekstu aktivnosti slobodnog vremena obitelji, interesima ostalih članova obitelji ili se lako pronalaze aktivnosti zato jer se one svode na one aktivnosti koje odgovaraju samo interesima djeteta. Neovisno o tome potonji iskaz majke ukazuje na važnost prilagodbe aktivnosti slobodnog vremena obitelji djetetu s teškoćama u razvoju kako bi obitelj prakticirala aktivnosti kojima bi se zadovoljili interesi što većeg broja članova obitelji.

Pa nije lako. Nije lako. Kažem, mislim samo kad krenemo od tih nekakvih društvenih igara koje nisu prilagođene svima i gdje je u stvari teško nać' društvenu igru koju mogu igrati svi. Pa, ne znam, do izlaska u grad gdje, u stvari, ima more fizičkih barijera. (M5)

Je. Ona je jako zainteresirano dijete... Što god da mi radimo, to možemo raditi sa njom. Da ona u nekoj mjeri može sudjelovat', mi to pojednostavimo koliko treba... Evo, na primjer, ako mi želimo igrati Čovječe, ne ljuti se, ona nije u stanju sjedit' i pratit'figure i to sve. Pa mi to napravimo da njoj približimo. Pa smo onda napravili veliki Čovječe, ne ljuti se, sa velim figurama, sa jarkim bojama, sa velikim kontrastom i napravili da mora šetat' $u$ krug da bi ona to igrala. I tako smo došli do toga da ona igra normalan Čovječe ne ljuti se. (M1)

Kao najpotrebnije resurse majke procjenjuju potrebu za stručnom podrškom i praktičnu pomoć. 
has to walk around in circles to play it. In the end, we have achieved that she plays the board game completely. (M1)

As the most necessary resources, mothers mentioned the need for professional support and practical help. In addition, they reported the need for rest, more flexible work hours for the husband, time and health; and of material resources, they mentioned money. Mothers' statements suggest the need for professional support and non-material resources in general, which differs from the results by Berc and Kokorić (2012), where parents indicated material resources, i.e. money, to be the most necessary. The authors of the present study suggest that the differences relate to the fact that the previous research did not focus on the parents of the children with developmental disabilities. However, that work is still worth mentioning due to the already mentioned lack of specific national and regional research.

In the whole story, maybe we would need the support of the system, personal assistants. Because we do not give our all to spend time together, far from it. But we definitely need the support of the system, we need assistants. Because you need help with bathing, you need help with taking him for a walk. (M2)

\section{STRATEGIES THAT PARENTS OF CHILDREN WITH DEVELOPMENTAL DISABILITIES USE FOR ACHIEVING FAMILY LEISURE}

The third research question gives us insight into the strategies that mothers of the children with developmental disabilities use for achieving family leisure. Mothers plan the time and the place of the family leisure activity in detail as well as the necessary resources for achieving an activity, which enables them to ensure more successful joint leisure. The results about the careful planning agree with previous findings on planning to secure the space and time for the family with a child with a developmental disability to be together (Segal, 2011). In addition, according to Boyd et al. (2014), Bagby, Dickie and Baranek (2012) confirm that various strategies to prepare food, location and time are used by families with a child with a disability.

It takes a lot of planning in order for a family of children with developmental disabilities to spend their
Usto, navode potrebu za odmorom, fleksibilnijim radnim vremenom supruga, vremenom i zdravljem, a od materijalnih resursa spominju novac. Iskazi majki sugeriraju potrebu za stručnom podrškom te općenito nematerijalnim resursima, što se razlikuje od rezultata Berc i Kokorić (2012), gdje roditelji kao najpotrebnije navode materijalne resurse, odnosno novac. Autorice sugeriraju kako razlike u tim rezultatima dijelom treba tražiti u tome što navedeno ranije istraživanje nije imalo fokus na roditelje djece s teškoćama u razvoju, ali je, s obzirom na već isticanu manjkavost usko profiliranih nacionalnih i regionalnih istraživanja, i dalje jednako vrijedno spomenuti.

U cijeloj toj priči, možda bi trebala podrška sustava, osobni asistenti. Jer mi, daleko od toga da ne dajemo sve od sebe da se skupa družimo... Ali nama definitivno treba podrška sustava, nama trebaju asistenti... Jer vi trebate i pomoć pri kupanju, vi trebate pomoć pri izvesti ga u šetnju. (M2)

\section{STRATEGIJE KOJE RODITELJI DJECE S TEŠKOĆAMA U RAZVOJU KORISTE ZA OSTVARIVANJE SLOBODNOG VREMENA OBITELJI}

Treće istraživačko pitanje daje uvid u strategije koje majke djece s teškoćama u razvoju koriste za ostvarivanje slobodnog vremena obitelji. Majke detaljno planiraju mjesto i vrijeme provođenja aktivnosti slobodnog vremena obitelji te potrebne resurse za ostvarivanje aktivnosti što im omogućava osiguravanje uspješnijeg zajedničkog slobodnog vremena. Rezultati koji govore o pažljivom planiranju slažu se s dosadašnjim nalazima o planiranju te osiguravanju prostora i vremena da bi obitelj s djetetom s teškoćama mogla biti zajedno (Segal, 2011). Također pripremanje različite hrane, planiranje lokacije i vremena kao strategije koje koriste obitelji djeteta s teškoćama u razvoju potvrdili su Bagby i sur. (2012) prema Boyd i sur. (2014).

Znači i da bi nekako familija s djecom s teškoćama provodila slobodno vrijeme korisno $i$ pametno potrebno je isto jako puno planiranja. Da, planiranje i organiziranje apsolutno strašno važna riječ.... (M9)

Osiguravanje rutine nije se pokazala kao praksa većine majki, a iskazi majki koje je prakticiraju suge- 
leisure in a useful and smart way. Yes, planning and organizing are extremely important words... (M9)

Ensuring routine was not a practice of the majority of mothers in our sample, and the statements of the mothers that do practise it suggest the importance of stimulation control in the environment and ensuring accessibility of the place where the activity is conducted. Not spending family leisure according to patterns is opposite to the findings of Schaaf et al. (2011), who found that families with a child with autism often ensure routines in order to increase experience predictability. The authors of the present study attribute this difference to the fact that the previous research was solely focused on families with a child with autism spectrum disorder, which is extremely specific considering that routine and ritualistic behaviour are one of the basic symptoms for diagnosing that condition (American Psychiatric Association, 2013), while the present research encompassed a broader spectrum of disabilities, as well as the need for routine.

Every day of the week is more or less the same. So, on Tuesdays, we visit the speech therapist on neurofeedback and swimming, and so, after school, we know exactly who goes where, how long we will be there, what comes after that, what is in the middle and where to go after. Yes, it means, leisure, he knows he doesn't go home, but that he will go somewhere and then we can sometimes talk in the car and say if we go to ***. (M7)

With the purpose of enabling and simplifying the participation of a child with a developmental disability in family leisure, the mothers ensure various materials and aids such as sensory materials, wheelchairs, therapy dogs, sports props and didactic games, taking into account the needs and interests of a child.

As an aid, we have a dog, he is very useful, he helps a lot and he really looks after her, but that is more or less that. We use only the things that help her and those are things like weights and massagers and those things... We are making her a sensory room. There was a sensory room in the previous flat too, with gym mats, a mirror, a hanging swing and such. And those are the things that really help because then you can play while doing something at the same time. (M1) riraju važnost kontrole podražaja u okolini te osiguravanja pristupačnosti mjesta provođenja aktivnosti. Neprovođenje slobodnog vremena obitelji prema rutinskim obrascima suprotno je nalazima Schaaf i sur. (2011) koji su utvrdili kako obitelji djeteta s poremećajem iz autističnog spektra često osiguravaju rutine s ciljem povećanja predvidljivosti iskustava. Razlike u nalazima ovog istraživanja i ovog ranije provedenog, autorice dijelom pripisuju tome što se ranije istraživanje fokusiralo samo na obitelji djeteta s poremećajem iz autističnog spektra, koji je izrazito specifičan s obzirom da su rutina i ritualna ponašanja jedan od temeljnih simptoma prilikom utvrđivanja istoga (Američka psihijatrijska udruga, 2014), dok je ovo istraživanje obuhvatilo širi spektar teškoća te, analogno tome, i potreba za rutinom.

Svaki dan u tjednu je otprilike jednak. Znači, utorak smo kod logopeda na neurofeedbacku i na plivanju i znači, poslije škole se točno zna gdje se ide, kol 'ko ćemo se tamo otprilike zadržat', šta je poslije toga, sta je između i kam'se ide poslije. Da, znači, slobodno vrijeme, on zna da ne ide doma, nego da će se negdje ić', al'onda se znamo nekad usput dogovarat' dal' ćemo ić na ****... (M7)

S ciljem omogućavanja i olakšavanja sudjelovanja djeteta s teškoćama u razvoju u aktivnostima slobodnog vremena obitelji, majke osiguravaju različite materijale i pomagala poput senzornih materijala, invalidskih kolica, terapijskog psa, sportskih rekvizita i didaktičkih igara, vodeći računa o potrebama $i$ interesima djeteta.

Od pomagala imamo psa, on je jako koristan, puno pomaže i dosta pazi na nju, ali više-manje je to to. Mi koristimo samo ove neke stvari koje njoj pomažu, a to su tipa utezi i masažeri i takve stvari... Uređujemo joj senzornu sobu. U prošlom je stanu isto bila senzorna soba, ono sa strunjačama, ogledalo, viseća ljuljačka i to. I to su zapravo stvari koje jako pomažu jer onda se možeš igrati usput dokjoš nešto tu radišs. (M1)

Kod govora o doprinosu literature o teškoćama u razvoju za ostvarivanje slobodnog vremena obitelji manji dio majki opisuje način na koji pročitana literatura pomaže u organiziranju slobodnog vremena obitelji pri čemu govore o boljem razumijevanju djeteta što onda ima implikacije i na uspješnije provođenje slobodnih aktivnosti. 
Hrvatska revija za rehabilitacijska istraživanja 2020, Vol 56, br. 1, str. 107-131

When talking about the contribution of the literature about the developmental disabilities for achieving family leisure, just a small number of mothers described ways in which the literature helps them organise family leisure. The mothers stated that the literature helps them better understand the child, which then has further implications on successful implementation of leisure.

Well, yes, as a young boy, ***, I mean, he still has that general sensory integration disorder, so that the literature I used was completely on that subject. So, how to regulate a child so you could even play with him or go somewhere and such things. I learned there, from that literature, a lot about the strategies on how to reduce stimuli or how to activate them... or how to reduce sound stimulation or how to motivate him and such things. That means that there is literature and it has helped me a lot. (M7)

Speaking of the support they get in planning and spending family leisure, the mothers mention family members, especially the husband, grandmother and grandfather of the child with a developmental disability, then the exchange of experience with other parents and cooperation with experts in various fields. Consulting others, as well as finding a way in which other family members can help them in planning and organising family leisure, are the strategies that mothers use in order to ensure family leisure.

Therapists are actually the people who give the best guidelines on what and how to do with a child... Here, a specific example: one year we went to the seaside and my husband wanted to rent a boat... I was terrified how *** will react, considering he had never been on a boat before... The first thing I did was to call his therapist who said nicely: "Ok, if he shows that [anxiety], sit, put a backpack on him." I think I would have never thought of that, him holding a backpack, to feel something on his body. (M6)

\section{BENEFITS OF LEISURE IN FAMILIES WITH CHILDREN WITH DEVELOPMENTAL DISABILITIES AND PARENTS' EXPERIENCE OF FAMILY LEISURE}

When responding to the fourth question, when talking of the benefits for the whole family, the
Pa da, **** je kao mali, odnosno još uvijek ima taj generalizirani poremećaj senzorne integracije, tako da se sva ta literatura svodila meni na to. Znači, kako dijete izregulirat'da bi ti mogao uopće s njim nešto se poigrat' ili na neko mjesto otić' i takve stvari. Tam'sam naučila, iz te literature, dosta o tim nekakvim strategijama kako smanjit' podražaje ili kako ih aktivirat'... ili kako smanjit' podražaje zvuka ili kako ga motivirat'i takve stvari. Znači, postoji literatura i dosta mi je u tome pomogla. (M7)

Od podrške koju dobivaju u planiranju i provođenju slobodnog vremena obitelji majke spominju članove obitelji, u vezi s čim spominju supruga, baku i djeda djeteta/djece s teškoćama u razvoju, zatim razmjenu iskustava $\mathrm{s}$ drugim roditeljima te suradnju sa stručnjacima raznih područja. Dakle konzultiranje s drugima, kao i pronalaženje načina na kojim im drugi članovi obitelji mogu pomoći u planiranju i organiziranju slobodnog vremena obitelji, predstavljaju strategije kojima majke osiguravaju slobodno vrijeme obitelji.

Terapeuti su ti koji zapravo daju najbolje smjernice što i kako raditi s djetetom... Evo, konkretno primjer: jedne godine smo bili na moru i suprug je htio iznajmit' nekakav gliser, brod... Ja sam se užasno bojala kako će ****na to reagirat', s obzirom na to da nije nikad prije bio... I prvo što sam napravila je nazvala njegovu terapeuticu koja mi je lijepo rekla: "Okej, ako on pokazuje to, sjedni, stavi na njega ruksak." Mislim ne bi'se tog nikad sjetila da on drži ruksak, da osjeti to nešto na tijelu. (M6)

\section{DOBROBITI SLOBODNOG VREMENA OBITELJI DJETETA $S$ TEŠKOĆAMA U RAZVOJU I RODITELJSKI DOŽIVLJAJ SLOBODNOG VREMENA OBITELJI}

Što se tiče četvrtog istraživačkog pitanja kod govora o dobrobitima za cijelu obitelj ispitanice prepoznaju bolju povezanost članova obitelji, bolju komunikaciju, jačanje povjerenja i osjećaja obitelji te razvijanje vještina rješavanja sukoba. Slično ovim rezultatima poboljšanje komunikacije i povezivanje članova obitelji i ranije su prepoznati kao doprinosi zajedničkog slobodnog vremena obitelji djeteta s teškoćama u razvoju (Mactavish i Schleien, 1998; Mactavish i Schleien, 2004). Navodeći dobrobiti 
mothers recognised better connection amongst family members, better communication, strengthening trust and family feeling and developing conflict management skills. Similar to these results, improving communication and connecting family members was recognised earlier as contributions of leisure in families with a child with a developmental disability (Mactavish \& Schleien, 1998; Mactavish \& Schleien, 2004). The greatest contributions for the child with a developmental disability that the mothers state most frequently is in terms of socialisation, speech and motor skills development and developing self-confidence, then they talk about happiness and entertaining a child and the child's relaxation. The above-mentioned is similar to recent findings according to which the most important benefits of leisure in families with a child with a developmental disability is the development of the child's skills, development of self-confidence and positive image and the experience of fun as well as the child's detachment from a stressful experience (Mactavish \& Schleien, 1998; Mactavish \& Schleien, 2004).

Similar to that, amongst the benefits for the child of a typical development the most recognisable is the contribution of family leisure to the child's development, especially in terms of empathy and maturity. When describing the family leisure benefits for themselves, the mothers mentioned relaxation the most, i.e. as relaxing and a source of strength. In addition, they see family leisure activities as useful for developing parents' competence, strengthening the sense of fulfillment and feeling of what is important in life, and they also mention their own happiness and an opportunity to have fun as positive outcomes. The feeling of parent's competence as a benefit of family leisure matches earlier findings by Downs (2008), who reported that parents of children with severe disabilities described family leisure activities as significant for a feeling of parents' effectiveness. When talking about the benefits for the child/children, the mothers in the present study stressed the developmental function of family leisure, and at the same time, when talking about the benefits for themselves, they mentioned "rest" more, which the authors connect to the notion of family leisure as leisure whose purpose is not just fun but also za dijete s teškoćama u razvoju, majke najviše spominju djetetov razvoj u terminima socijalizacije, razvoja govora i motorike te razvoja pozitivnog samopoimanja, zatim govore o sreći i zabavljanju djeteta te djetetovu opuštanju. Navedeno je slično dosadašnjim nalazima prema kojima se kao najvažnije dobrobiti slobodnog vremena obitelji djeteta s teškoćama u razvoju navode razvoj vještina djeteta, razvoj samopouzdanja i pozitivnog samopoimanja djeteta te iskustvo zabave kao i djetetovo odmicanje od stresnog iskustva (Mactavish i Schleien, 1998; Mactavish i Schleien, 2004).

Slično tome kod prepoznavanja dobrobiti za dijete tipična razvoja najviše se prepoznaje doprinos slobodnog vremena obitelji za razvoj djeteta, osobito u vidu empatije i zrelosti. Opisujući dobrobiti slobodnog vremena obitelji za sebe same, majke najviše spominju odmor, odnosno opuštanje i izvor snage. Usto aktivnosti slobodnog vremena obitelji vide kao korisne za razvijanje roditeljske kompetentnosti, jačanja osjećaja ispunjenosti te osjećaja za ono što je u životu važno, a također navode vlastitu sreću i priliku za zabavljanje kao pozitivne ishode. Doživljaj roditeljske kompetentnosti kao dobrobiti slobodnog vremena obitelji odgovara ranijim nalazima Downs (2008) koja izvještava o iskazima roditelja djece s više vrsta i stupnjeva teškoća u psihofizičkom razvoju, a koji aktivnosti slobodnog vremena obitelji opisuju kao značajne za osjećaj roditeljske učinkovitosti. Dakle kod govora o dobrobitima za dijete/djecu majke više naglašavaju razvojnu funkciju slobodnog vremena obitelji, dok kod govora o dobrobitima za sebe češće spominju odmor, što autorice povezuju s poimanjem slobodnog vremena obitelji kao namjernim slobodnim vremenom kojem cilj nije samo zabava već poticanje razvijanja vještina djeteta. Na pitanje mogu li slobodno vrijeme obitelji doživjeti kao slobodno vrijeme, majke su se pokazale podijeljenima. Majke koje ga opisuju kao svoje slobodno vrijeme takvim ga opisuju iz različitih razloga sugerirajući kako ono treba predstavljati izvor opuštanja i snage da bi ga takvim mogle doživjeti. Majke koje slobodno vrijeme obitelji ne opisuju u terminu slobodnog vremena navedeno najviše objašnjavaju udjelom obveza koje ono uključuje.

Definitivno, kao i moje slobodno vrijeme. Mislim, meni je ta, ta šetnja, evo sad, jako se vese- 
Hrvatska revija za rehabilitacijska istraživanja 2020, Vol 56, br. 1, str. 107-131

to develop the child's skills. When asked if they can see family leisure as leisure, the mothers were divided. The mothers who described it as their own leisure described it as such for various reasons, suggesting that it represented a source of relaxation and strength in order for them to be able to see it as such. The mothers who did not describe the family leisure in terms of leisure explained that this was because of the number of obligations it entailed.

Definitely, as my leisure. I mean, that walk is, for me, like now, I am really looking forward to these nice days, to me that walk in the afternoon... Then let's go to the wheelchair and let's go for a walk, you know... That is something too, it is relaxing, because, I really just push the wheelchair and I walk... So, I consider it my leisure. (M6)

When you are with them, it is like you are on needles, you dread it, constantly running here and there, essentially... You are stressed all the time. It means you don't really have completely leisure. (M4)

Most mothers mentioned the source of relaxation as a family leisure benefit for themselves, but at the same time some of them did not describe family leisure as leisure. The authors of the present study believe that these findings reflect the complexity of the phenomenon of leisure in families with a child with a developmental disability, in which there can coexist both positive and negative experiences; even though leisure can contribute to relaxation and mothers' satisfaction in certain instances, it can also involve obligations and lack of satisfaction. Despite the latter, the statements on the recognised benefits suggest that mothers recognise family leisure as an important segment of family life that can contribute to each individual family member and the family as a whole.

\section{CONCLUSION}

All of the above-mentioned very clearly underlines the fact that primarily in the national framework, the topic of leisure in families with children with disabilities is very relevant, although the present research has only scratched the surface. This research generated some topics the authors believe to be valuable for further research. For example, it would be useful to research the level and the form lim ovim lijepim danima, meni je ta šetnja popodne, ono... Onda 'ajmo u kolica i idemo šetat', znači... I to je nešto, ono u meni opuštanje jer ja to, u principu, guram kolica i hodam...Tako da, da, smatram to svojim slobodnim vremenom. (M6)

Kad si s njima, opet si na nekim iglama, opet nešto strepiš, opet nešto, stalno trčiš simo tamo, $u$ biti... Konstanto si napet. Znači, da ti imaš neko potpuno slobodno vrijeme, nemaš. (M4)

Kako većina majki spominje izvor odmora kao dobrobit slobodnog vremena obitelji za sebe same, ali dio njih istovremeno slobodno vrijeme obitelji ne opisuje kao slobodno vrijeme, autorice procjenjuju kako takvi iskazi upućuju na kompleksnost fenomena slobodnog vremena obitelji djeteta $s$ teškoćama u razvoju u kojemu mogu istovremeno koegzistirati i pozitivna i negativna iskustva te iako ono u nekim segmentima može pridonijeti odmoru i zadovoljstvu majki, također može uključivati obveze i izostanak zadovoljstva. Unatoč potonjem iskazi o prepoznatim dobrobitima sugeriraju kako majke prepoznaju slobodno vrijeme obitelji kao bitan segment obiteljskog života koji može pridonijeti svakom pojedinom članu obitelji i obitelji kao cjelini.

\section{ZAKLJUČAK}

Sve navedeno vrlo jasno potkrepljuje činjenicu kako je, primarno u nacionalnim okvirima, tematika slobodnoga vremena obitelji djeteta s teškoćama očigledno itekako relevantna, istraživački tek načeta te da je ovo istraživanje generiralo neke teme koje autorice drže vrijednima za daljnja detaljnija ispitivanja. Primjerice stupanj i oblik interakcije članova obitelji tijekom slobodnog vremena obitelji djeteta s teškoćama u razvoju bilo bi korisno istražiti metodom opažanja. Način na koji se slobodno vrijeme obitelji djeteta s teškoćama u razvoju razlikuje među obiteljima djece s teškoćama u razvoju $\mathrm{s}$ obzirom na različite identitetske markere moglo bi se istražiti kvantitativnim nacrtom istraživanja, primjerice: postoje li razlike u slobodnom vremenu obitelji djeteta s teškoćama u razvoju s obzirom na rod ili stupanj obrazovanja roditelja? Autorice procjenjuju kako bi navedeno moglo pridonijeti bogaćenju spoznaje o slobodnom vremenu obitelji djeteta s teškoćama u razvoju. 
of interaction of the family members during leisure in families with a child with a developmental disability using an observational method. The way that leisure in families with a child with a developmental disability differs amongst families with a child with a developmental disability considering various identification markers could be researched using a quantitative research plan. For example, are there any differences in leisure in families with a child with a developmental disability considering the gender or the level of education of the parents? The authors suggest such research could contribute to furthering the knowledge of leisure in families with a child with a developmental disability.

However, it is also necessary to point out the possible limitations of the present study. One is the small convenience sample, especially considering that four out of nine mothers were mothers with a child with autism spectrum disorder, which is specific, especially in relation to the activity classification used in the research. In addition, it is important to mention the lack of fathers' perspective, the possibility of giving socially desirable answers and the subjectivity of the authors, especially in the data analysis segment and especially when classifying leisure activities, which was based on the interpretation of the mothers' statements. This may lead to bias when taking into consideration the perception of a certain activity as core or balance from the mothers' perspective. The authors suggest introducing the parents to the notions of core and balance activities in further research, and asking parents to state whether certain activities were core or balance for them, since this assessment may differ from that of the researchers. In addition, the authors suggest an interpretation of core or balance in accordance with the child's disability. For example, a core activity for a child with autism spectrum disorder cannot be interpreted in the same way as in a child with a different disability.

Furthermore, some disadvantages can be ascribed to the interview protocol, such as leaving out the option for mothers themselves to define their family leisure. In terms of testing the strategies at the end of each interview, the mothers were given an opportunity to add something that they considered to be associated with the topic but was not mentioned. They did not mention a new topic
Ipak, valja ukazati i na njegove moguće nedostatke. Kao moguća ograničenja provedenog istraživanja autorice sugeriraju prigodan i malen uzorak, osobito ako se u obzir uzme da su od devet ispitanica njih četiri bile majke djeteta s poremećajem iz autističnog spektra, koji je specifičan, posebice u odnosu na klasifikaciju aktivnosti korištenu $\mathrm{u}$ istraživanju.

Usto valja spomenuti izostavljanje perspektive očeva, mogućnost davanja društveno poželjnih odgovora te subjektivnost autorica, posebice u segmentu analize podataka, osobito kod podjele slobodnovremenskih aktivnosti koja se temeljila na interpretaciji iskaza ispitanica potencijalno nedovoljno uzimajući u obzir poimanje pojedine aktivnosti kao bazične ili uravnotežujuće od strane ispitanica. Autorice stoga predlažu da se u daljnjim istraživanjima roditelje upozna s terminima bazične i uravnotežujuće aktivnosti te da se više ide u smjeru značenja koja roditelji pridaju tome jesu li pojedine aktivnosti za njih bazične ili uravnotežujuće, jer se ovako procjena autorica o pojedinim aktivnostima mogla razlikovati od roditeljskog doživljaja istih. Također autorice predlažu tumačenje odgovora temeljenih na navedenoj podjeli aktivnosti ovisno o djetetovoj teškoći jer primjerice bazična aktivnost za dijete s poremećajem iz autističnog spektra ne može biti tumačena na jednak način kao i kod djeteta s drugačijom teškoćom.

Nadalje dio nedostataka može se pripisati i samom protokolu intervjua kao što je izostavljanje mogućnosti da majke same definiraju slobodno vrijeme obitelji. Također u sklopu ispitivanja strategija na kraju svakog intervjua ispitanicama je dana mogućnost da nadodaju nešto što smatraju povezanim s temom, a što nije spomenuto, pri čemu se nisu pojavile nove teme povezane sa strategijama. Usprkos tome autorice iznose prijedlog da se u narednim istraživanjima neposredno nakon ispitivanja o strategijama ispitanice potakne na mogućnost iznošenja strategija za koje procjenjuju da ih koriste, a koje nisu predložene u protokolu intervjua, čime bi se potencijalno obogatila spoznaja o navedenom momentu. Naposljetku kod pitanja o lakoći pronalaska aktivnosti, za bogatiji uvid u pronalaženje odgovarajućih aktivnosti, predlaže se dodavanje pitanja o tome koliko članovi obitelji lako dogovaraju aktivnosti koje će provoditi 
connected to the strategies. Despite that, the authors propose a new approach for further research. Immediately after the strategy questions, the mothers are to be encouraged to mention strategies they use that were not suggested in the interview protocol, and that would potentially enrich knowledge on subject. Lastly, to investigate the ease of finding certain activities, it is suggested that a question be added asking how easily family members agree on activities they will spend together, who participates in making that decision and in what way. All of the above-mentioned confirms the complexity and consequently the necessity of further research on the phenomenon of leisure in families with a child with a developmental disability. zajedno te tko i na koji način u tom dogovaranju i odlučivanju sudjeluje. Sve navedeno dodatno potvrđuje kompleksnost te posljedično i nužnost daljnjeg istraživanja fenomena slobodnog vremena obitelji djeteta s teškoćama u razvoju. 


\section{REFERENCES}

American Psychiatric Association (2014). Diagnostic and Statistical Manual of Mental Disorders: DSM-5. Jastrebarsko: Naklada Slap.

Axelsson, K. A., Wilder, J. (2014). Frequency of occurrence and child presence in family activities: A quantitative, comparative study of children with profound intellectual and multiple disabilities and children with typical development. International Journal of Developmental Disabilities, 60(1), 13-25. https://doi.org/10.1179/2047387712Y.0000000008

Berc, G., Kokorić, S. B. (2012). Slobodno vrijeme obitelji kao čimbenik obiteljske kohezivnosti i zadovoljstva obiteljskim životom. Kriminologija $i$ socijalna integracija, 20(2), 1-89.

Boyd, B., Harkins McCarty, C., Sethi, C. (2014). Families of children with autism: A synthesis of family routines literature. Journal of Occupational Science, 21(3), 322-333. https://doi.org/10.1080/14 427591.2014 .908816

Clarke, H. (2006). Preventing social exclusion of disabled children and their families: Literature review paper produced for the National evaluation of the Children's Fund (Report No. 782). Birmingham: Institute of Applied Social Studies, University of Birmingham. Retrieved 23.10.2019. from http:// dera.ioe.ac.uk/6462/1/RR782.pdf.

DeGrace, B. W. (2004). The everyday occupation of families with children with autism. American Journal of Occupational Therapy, 58(5), 543-550. https://doi.org/10.5014/ajot.58.5.543

DeGrace, B. W., Hoffman, C., Hutson, T. L., Kolobe, T. H. A. (2014). Families' experiences and occupations following the diagnosis of autism. Journal of Occupational Science, 21(3), 309-321. https://doi. org/10.1080/14427591.2014.923366.

Dodd, D. C. H., Zabriskie, R. B., Widmer, M. A., Eggett, D. (2009). Contributions of family leisure to family functioning among families that include children with developmental disabilities. Journal of Leisure Research, 41(2), 261-286. https://doi.org/10.1080/ 00222216.2009 .11950169 .

Downs, M. (2008.) Leisure routines: Parents and children with disability sharing occupation. Journal of Occupational Science, 15(2), 105-110. https://doi. org/10.1080/14427591.2008.9686616

\section{LITERATURA}

Američka Psihijatrijska Udruga (2014). Dijagnostički $i$ statistički priručnik za duševne poremećaje: DSM-5. Jastrebarsko: Naklada Slap.

Axelsson, K. A., Wilder, J. (2014). Frequency of occurrence and child presence in family activities: A quantitative, comparative study of children with profound intellectual and multiple disabilities and children with typical development. International Journal of Developmental Disabilities, 60(1), 13-25. https://doi.org/10.1179/2047387712Y.0000000008

Berc, G., Kokorić, S. B. (2012). Slobodno vrijeme obitelji kao čimbenik obiteljske kohezivnosti i zadovoljstva obiteljskim životom. Kriminologija $i$ socijalna integracija, 20(2), 1-89.

Boyd, B., Harkins McCarty, C., Sethi, C. (2014). Families of children with autism: A synthesis of family routines literature. Journal of Occupational Science, 21(3), 322-333. https://doi.org/10.1080/14 427591.2014.908816

Clarke, H. (2006). Preventing social exclusion of disabled children and their families: Literature review paper produced for the National evaluation of the Children's Fund (Report No. 782). Birmingham: Institute of Applied Social Studies, University of Birmingham. Preuzeto 23.10.2019. s http://dera. ioe.ac.uk/6462/1/RR782.pdf.

DeGrace, B. W. (2004). The everyday occupation of families with children with autism. American Journal of Occupational Therapy, 58(5), 543-550. https://doi.org/10.5014/ajot.58.5.543

DeGrace, B. W., Hoffman, C., Hutson, T. L., Kolobe, T. H. A. (2014). Families' experiences and occupations following the diagnosis of autism. Journal of Occupational Science, 21(3), 309-321. https://doi. org/10.1080/14427591.2014.923366

Dodd, D. C. H., Zabriskie, R. B., Widmer, M. A., Eggett, D. (2009). Contributions of family leisure to family functioning among families that include children with developmental disabilities. Journal of Leisure Research, 41(2), 261-286. https://doi.org/10.1080/ 00222216.2009 .11950169

Downs, M. (2008). Leisure routines: Parents and children with disability sharing occupation. Journal of Occupational Science, 15(2), 105-110. https://doi. org/10.1080/14427591.2008.9686616 
Hebblethwaite, S. (2015). Understanding ambivalence in family leisure among three-generation families: „It's all part of the package“. Annals of Leisure Research, 18(3), 359-376. https://doi.org/10.1080 $/ 11745398.2015 .1063443$

Hodge, C., Bocarro, J. N., Henderson, K. A., Zabriskie, R., Parcel, T. L., Kanters, M. A. (2015). Family Leisure: An Integrative Review of Research from Select Journals. Journal of Leisure Research, 47(5), 577-600. https://doi.org/10.18666/jlr-2015v47-i5-5705

Hsieh, H. F., Shannon, S. E. (2005). Three approaches to qualitative content analysis. Qualitative Health Research, 15(9), 1277-1288. https://doi. org/10.1177\%2F 1049732305276687

Janković, J. (1973). Slobodno vrijeme u suvremenoj pedagoškoj teoriji I praksi. Zagreb: Pedagoškoknjiževni zbor.

Mactavish, J., Schleien, S. (1998). Playing together growing together: Parents' perspectives on the benefits of family recreation in families that include children with a developmental disability. Therapeutic Recreation Journal, 32(3), 207-230. Retrieved 23.10.2019. from https://libres.uncg.edu/ ir/uncg/f/Schleien_S_Playing_1998.pdf.

Mactavish, J., Schleien, S. (2000). Exploring family recreation activities in families that include children with developmental disabilities. Therapeutic Recreation Journal, 34(2), 132-153. Retrieved 23.10.2019. from https://libres.uncg.edu/ir/uncg/f/ Schleien_S_Exploring_2010.pdf

Mactavish, J., Schleien, S. (2004). Re-injecting spontaneity and balance in family life: Parents' perspectives on recreation in families that include children with developmental disability. Journal of Intellectual Disability Research, 48(2), 133-141. Retrieved 23.10.2019. from https://libres.uncg.edu/ ir/uncg/f/S_Schleien_ReInjecting_2004.pdf

McCabe, S. (2015). Family leisure, opening a window on the meaning of family. Annals of Leisure Research, 18(2), 175-179. https://doi.org/10.1080/ 11745398.2015 .1063748

Melton, K. (2017). Family activity model: Crossroads of activity environment and family interactions in family leisure. Leisure Sciences, 39(5), 457-473. https://doi.org/10.1080/01490400.2017.1333056
Hebblethwaite, S. (2015). Understanding ambivalence in family leisure among three-generation families: "It's all part of the package". Annals of Leisure Research, 18(3), 359-376. https://doi.org/10.1080 $/ 11745398.2015 .1063443$

Hodge, C., Bocarro, J. N., Henderson, K. A., Zabriskie, R., Parcel, T. L., Kanters, M. A. (2015). Family Leisure: An Integrative Review of Research from Select Journals. Journal of Leisure Research, 47(5), 577-600. https://doi.org/10.18666/jlr-2015v47-i5-5705

Hsieh, H. F., Shannon, S. E. (2005). Three approaches to qualitative content analysis. Qualitative Health Research, 15(9), 1277-1288. https://doi. org/10.1177\%2F1049732305276687

Janković, J. (1973). Slobodno vrijeme u suvremenoj pedagoškoj teoriji i praksi. Zagreb: Pedagoškoknjiževni zbor.

Mactavish, J., Schleien, S. (1998). Playing together growing together: Parents' perspectives on the benefits of family recreation in families that include children with a developmental disability. Therapeutic Recreation Journal, 32(3), 207-230. Preuzeto 23.10.2019. s https://libres.uncg.edu/ir/ uncg/f/Schleien_S_Playing_1998.pdf.

Mactavish, J., Schleien, S. (2000). Exploring family recreation activities in families that include children with developmental disabilities. Therapeutic Recreation Journal, 34(2), 132-153. Preuzeto 23.10.2019. s https://libres.uncg.edu/ir/uncg/f/ Schleien_S_Exploring_2010.pdf.

Mactavish, J., Schleien, S. (2004). Re-injecting spontaneity and balance in family life: Parents' perspectives on recreation in families that include children with developmental disability. Journal of Intellectual Disability Research, 48(2), 133-141. Preuzeto 23.10.2019. s https://libres.uncg.edu/ir/ uncg/f/S_Schleien_ReInjecting_2004.pdf.

McCabe, S. (2015). Family leisure, opening a window on the meaning of family. Annals of Leisure Research, 18(2), 175-179. https://doi.org/10.1080 $/ 11745398.2015 .1063748$

Melton, K. (2017). Family activity model: Crossroads of activity environment and family interactions in family leisure. Leisure Sciences, 39(5), 457-473. https://doi.org/10.1080/01490400.2017.1333056 
Ombudsman for persons with disabilities. (2017). Report on the work for 2017. Zagreb: The office of the ombudswoman for persons with disabilities. Retrieved 23.10.2019. from http://posi.hr/wp-content/uploads/2018/04/ Izvje\%C5\%A1\%C4\%87e-o-radu-Pravobraniteljaza-osobe-s-invaliditetom-2017..pdf.

Ordinance on the Rights of Parents of a Child with More Serious Developmental Disabilities to Leave or Work Half-Time to Care for the Child. Official Gazette "Narodne Novine", 92/03.

Primary and Secondary Education Act. Official Gazette "Narodne novine", 87/08.

Regulations on Primary and Secondary Education of Students with Developmental Disabilities. Official Gazette "Narodne novine", 24/15.

Rešetar, B. (2017). Prava djece s invaliditetom - prava djece s problemima mentalnog zdravlja. Socijalna psihijatrija, 45(1), 4-15.

Rodger, S., Umaibalan, V. (2011). The routines and rituals of families of typically developing children compared with families of children with autism spectrum disorder: An exploratory study. British Journal of Occupational Therapy, 74(1), 20-26. https://doi.org/10.4276\%2F03080221 1X12947686093567

Schaaf, R. C., Toth-Cohen, S., Johnson, S. L., Outten, G., Benevides, T. W. (2011). The everyday routines of families of children with autism: Examining the impact of sensory processing difficulties on the family. SAGE Journals, 15(3), 373-389. https://doi. org/10.1177\%2F1362361310386505

Segal, R. (2011). Doing for others: Occupations within families with children who have special needs. Journal of Occupational Science, 6(2), 53-60. https://doi.org/10.1080/14427591.1999.9686451

Shaw, S. M., Dawson, D. (2001). Purposive leisure: Examining parental discoursers on family activities. Leisure Sciences, 23(2), 217-231. https://doi. org/10.1080/01490400152809098

Social Welfare Act. Official Gazette "Narodne novine", $33 / 13$.

Visković, I. (2016). Odgojno-obrazovni aspekti igre djece i roditelja u obitelji. In H. Ivon \& B. Mendeš (Eds.), Dijete, igra, stvaralaštvo (pp. 203-211). Split: Filozofski fakultet i Savez društava "Naša djeca".
Pravilnik o osnovnoškolskom i srednjoškolskom odgoju i obrazovanju učenika s teškoćama u razvoju. Narodne novine, 24/15.

Pravilnik o pravima roditelja djeteta s težim smetnjama u razvoju na dopust ili na rad s polovicom punog radnog vremena radi njege djeteta. Narodne novine, 92/03.

Pravobranitelj za osobe s invaliditetom (2017). Izvješće o radu za 2017. godinu. Zagreb: Pravobraniteljica za osobe s invaliditetom. Preuzeto 23.10.2019. s http://posi.hr/wp-content/uploads/2018/04/ Izvje $\% \mathrm{C} 5 \% \mathrm{~A} 1 \% \mathrm{C} 4 \% 87 \mathrm{e}$-o-radu-Pravobraniteljaza-osobe-s-invaliditetom-2017..pdf

Rešetar, B. (2017). Prava djece s invaliditetom - prava djece s problemima mentalnog zdravlja. Socijalna psihijatrija, 45(1), 4-15.

Rodger, S., Umaibalan, V. (2011). The routines and rituals of families of typically developing children compared with families of children with autism spectrum disorder: An exploratory study. British Journal of Occupational Therapy, 74(1), 20-26. https://doi.org/10.4276\%2F03080221 1X12947686093567

Schaaf, R. C., Toth-Cohen, S., Johnson, S. L., Outten, G., Benevides, T. W. (2011). The everyday routines of families of children with autism: Examining the impact of sensory processing difficulties on the family. SAGE Journals, 15(3), 373-389. https://doi. org $/ 10.1177 \% 2 \mathrm{~F} 1362361310386505$

Segal, R. (2011). Doing for others: Occupations within families with children who have special needs. Journal of Occupational Science, 6(2), 53-60. https://doi.org/10.1080/14427591.1999.9686451

Shaw, S. M., Dawson, D. (2001). Purposive leisure: Examining parental discoursers on family activities. Leisure Sciences, 23(2), 217-231. https://doi. org/10.1080/01490400152809098

Visković, I. (2016). Odgojno-obrazovni aspekti igre djece i roditelja u obitelji. U: H. Ivon i B. Mendeš (ur.), Dijete, igra, stvaralaštvo (str. 203-211). Split: Filozofski fakultet i Savez društava "Naša djeca".

Zabriskie, R. B., McCormick, B. P. (2001). The influences of family leisure patterns on perceptions of family functioning. Family Relations, 50(3), 281-289. https://doi.org/10.1111/j.17413729.2001.00281.x 
Zabriskie, R. B., McCormick, B. P. (2001). The influences of family leisure patterns on perceptions of family functioning. Family Relations, 50(3), 281-289. https://doi.org/10.1111/j.17413729.2001.00281.x
Zakon o odgoju i obrazovanju u osnovnoj i srednjoj školi. Narodne novine, 87/08.

Zakon o socijalnoj skrbi. Narodne novine, 33/13. 